Vol. 11, n 1 | 2007

Varia

\title{
René Lévy, Amy Gilman Srebnick (eds.), Crime and culture. An historical perspective
}

Aldershot, Ashgate, 2005

Pieter Spierenburg

\section{(2) OpenEdition}

\section{Journals}

Electronic version

URL: https://journals.openedition.org/chs/178

DOI: $10.4000 /$ chs. 178

ISSN: 1663-4837

\section{Publisher}

Librairie Droz

Printed version

Date of publication: 1 June 2007

Number of pages: 152-154

ISBN: 978-2-600-01160-0

ISSN: $1422-0857$

\section{Electronic reference}

Pieter Spierenburg, "René Lévy, Amy Gilman Srebnick (eds.), Crime and culture. An historical perspective", Crime, Histoire \& Sociétés / Crime, History \& Societies [Online], Vol. 11, n¹ | 2007, Online since 19 January 2009, connection on 23 March 2022. URL: http://journals.openedition.org/chs/178 ; DOI: https://doi.org/10.4000/chs. 178

This text was automatically generated on 23 March 2022.

(C) Droz 


\section{René Lévy, Amy Gilman Srebnick (eds.), Crime and culture. An historical perspective}

Aldershot, Ashgate, 2005

Pieter Spierenburg

\section{REFERENCES}

René Lévy, Amy Gilman Srebnick (eds.), Crime and culture. An historical perspective, Aldershot, Ashgate, 2005.

1 The reader expects me to write nothing but a positive review of this collection, which has several long-time colleagues among its contributors. Luckily, I don't have to be insincere. Indeed, something would be substantially wrong with the field of crime history if a number of its principal practitioners produced a bad book together. As a reviewer, I am an outsider of sorts, because I was visiting in the US and hence unable to attend the conference on which this collection is based. Its overall theme, disguised by its rather general title, is narrative and story-telling in relation to historical crime and justice. This still is a broad perspective, so the best way to review the book is to briefly summarize the individual contributions.

2 In the introduction, Amy Srebnick reviews the work of a number of philosophers, historians and novelists who have dealt with the subject of narrative. There is a basic continuity, she argues, instead of a neat distinction, between fictional and historical accounts of «tragedies.» In both cases, the narrator imposes his or her own order over the events.

3 The first section is concerned with the narratives contained in early criminological writing. Peter Becker summarizes the main arguments from his seminal Verderbnis und Entartung, which is useful since this book is not available in English. In Germany in the 1870 s a fundamental change took place in the type of discourse about crime. Until then, 
a practical and biographical approach, analyzing the career of individual Gauner, had prevailed. The authors in question claimed intimate knowledge of professional criminals and their way of life. The new approach, influenced by the reception of Lombroso but not confined strictly to criminologists, was more academic. Its representatives claimed scholarly authority, but their personal distance to offenders, whom they viewed as degenerates, was much greater. Mary Gibson focuses on the Italian school, analyzing three popularizing articles by Lombroso and his followers. She argues that the well-known contradictions and selective presentation of the evidence, already criticized in Lombroso's time, make sense when we consider his reading public. Most readers already believed in biological causes of crime and the existence of born criminals. To convince them even more, the Lombrosians made use of impressivelooking statistics for one readership and exemplary case-stories for another. Herbert Reinke closes this section with an essay on Robert Heindl's study of professional criminals, first published in 1926 and influential under various regimes into the 1950s. Implicitly, Reinke demonstrates that the older tradition of the practical «gaze» survived the rise of a scientific criminology in Germany.

4 Section Two interprets the overall theme of narrative and story-telling most liberally. It is concerned with various episodes in police history, in three countries, with an emphasis on the reconstruction of events. Allen Steinberg deals primarily with tales that were current in the period he studied: New York City in the 1890s and the early twentieth century. It was widely believed then that the underworld of gambling and prostitution enterprises controlled the city government and much of the judiciary. A few moral crusaders tried to alter that situation. Steinberg's story begins with and culminates in the murder of a minor gangster on the orders of a police officer, who eventually ended his life in the electric chair for it. By contrast, the London police of the 1920s and 1930s appears less corrupt. Clive Emsley deals with one notorious exception in 1929, in which Scotland Yard proudly proclaimed that they had eliminated a rotten apple by their own initiative. A few more incidents and the record of dismissals of policemen, however, suggest that the amount of unpalatable fruit might have been greater. The two other articles in this section take us to France. Jean-Marc Berlière discusses the purging of the (Vichy) police at the end of the Second World War. In this case, the outcome of the operation was heavily dependent on stories: Had individual policemen taken action against members of the Resistance, for example, and had they inevitably followed orders or had they pursued with enthusiasm what they could have prevented from happening? Even some of the accused managed to render an event in such a way that the main blame fell upon someone else. René Lévy's contribution on controlled deliveries of drugs in the 1990s covers the most recent period in this collection. He shows that the law usually follows police practice, that is illegal types of operations are subsequently legalized, thus making the French war on drugs similar to the American one (which, in the European view, often comes down to entrapment).

The last section is on the representation of criminals and crime. Pascal Bastien argues that, as executions became less frequent in late-eighteenth-century Paris, the publication of so-called arrêts, motivating the sentence, took their place. It should be added that the declining frequency was due to a transfer of the execution of appeal sentences to the original location, so this is no proof of a decrease in capital punishment in France. In Xavier Rousseaux's contribution the stories are primarily those of historians and literary writers after the events, which consisted of the Peasants' War in Belgian departments under French rule in 1798. Was it simple 
banditry or resistance against foreign rule or something other still and were the rebels reactionaries or progressives? The answer depended on whether a writer was Catholic or Liberal, Walloon or Flemish, with the Socialists coming in later. This discussion easily links up with that of the next contribution, by Mónika Mátay and György Csepeli, on Hungarian highwaymen. The authors refer to the well-known debate about brigandage between Hobsbawm and Blok, but since little is known about the actual behavior of bandits, the focus is on posthumous myths, which ranged widely from Robin Hood to aristocratic cavalier, including a new life in America. Then Wilbur Miller takes the reader to America as well, analyzing detective stories which proliferated in the period 1880-1920. These stories focused on individual heroes who waged battles on criminal organizations.

6 Let me make just two critical remarks: Bastien chooses to ignore much of the vast historical literature on execution ritual and Srebnick consistently misspells Carlo Ginzburg's name as Ginsburg, thus making him a hybrid of Carlo and Allen. For the rest, these are all enjoyable articles.

\section{AUTHORS}

\section{PIETER SPIERENBURG}

Faculteit Historischen Kustwetenschappen, Erasmus Universiteit Rotterdam, Postbus 1738, NL-3000 DR Rotterdam, spierenburg@fhk.eur.nl 